\title{
Taking Responsibility for Intergenerational Harms: Indian Residential Schools Reparations in Canada
}

\author{
Maegan Hough*
}

\begin{abstract}
From 2009 to 2012 the author lived and worked in Whitehorse as a lawyer for Justice Canada. One of her responsibilities was to attend Independent Assessment Process hearings in the role of "Canada's Representative." The experience of hearing from survivors and working within the limits of a tortsbased process sent the author on an exploration of how harms are classified and remedied in Canadian law. The disconnect she felt between the narrow parameters of the legal process and the ongoing effects of historic harms that were evident in many aspects of northern life needed to be reconciled. Building on previous work that identified and classified harms, the author reviews the thirteen reparations that have been provided for the harms caused by the Indian Residential Schools policy in order to assess how well these reparations, when taken together, are able to address the full range of harms expressed by residential school survivors. The author then suggests additional mechanisms of responsibility, drawn largely from transitional justice theories, which could bring Canadians, as individuals and as a polity, into their role within the intergenerational legacy of the Indian Residential Schools policy and recognize the full range of harms experienced by survivors.
\end{abstract}




\section{Table of Contents}

I. Introduction: Making the Personal Societal

II. Mechanisms of Responsibility

A. Criminal Prosecutions

B. Civil Litigation and Settlement

C. The Royal Commission on Aboriginal Peoples

D. The 1998 Statement of Reconciliation

E. The Aboriginal Healing Foundation

F. The Pilot Projects

G. The Alternative Dispute Resolution Program

H. The IRSSA: Funding for Healing

I. The IRSSA: Funding for Commemoration

J. The IRSSA: The Common Experience Payment

K. The IRSAA: The Independent Assessment Process

L. The IRSAA: The Truth and Reconciliation Commission

M. The 2008 Statement of Apology

N. (Institutional Support)

III. Responsibility for Canada

A. The Recent Past

1. Restatement of Harms

2. Restatement of Responsibilities

3. Responding Reflexively

B. Engaging Canadians

1. Apologies

2. Commemoration

3. Education

4. Storytelling

5. (More) Institutional Support

6. Canada's Representatives

IV. Conclusion 
To the Commission, "reconciliation" is about establishing and maintaining a mutually respectful relationship between Aboriginal and non-Aboriginal peoples in this country. For that to happen, there has to be awareness of the past, acknowledgement of the harm that has been inflicted, atonement for the causes, and action to change behaviour.

-Truth and Reconciliation Commission of Canada Final Report ${ }^{1}$

\section{Introduction: Making the Personal Societal}

As a young lawyer working in Whitehorse, Yukon, I attended Independent Assessment Process (IAP) hearings as part of the Indian Residential Schools Settlement Agreement (IRSAA). I found this work to be deeply unsettling as a proud Canadian. Seeing a negative vision of "Canada" reflected back to me through the eyes of Indian Residential Schools (IRS) survivors forced me to reflect upon my heritage as a non-Indigenous Canadian and my role in those hearing rooms as a representative of the Canadian government. At times this process of reflection left me paralyzed and at others it made me argumentative- I was alternately incapable of articulating my thoughts and belligerent towards any friends, coworkers, or unwitting strangers who I (often arbitrarily) judged inadequate in their knowledge or actions.

In order to understand my reaction, to continue to perform my job, and be able to live in a small centre where I regularly met survivors at the grocery store, I needed to understand my role in the IRS legacy as a Canadian. It was a deeply personal process undertaken as part of graduate studies, which I have written about elsewhere. ${ }^{2}$

Then, as now, I wrote from the perspective of a Canadian who has French and English ancestry and speaks those languages, is trained as a lawyer, has travelled across the country and lived in the North, on the West Coast, and in the "centre," and has worked, proudly, as a public servant for over a decade. My love for, and my pride in, my family, my friends, and my Northern Ontario roots have made me anxious to find ways to look positively on individual Canadians, both past and present, but have not blinded me to the effects of my ancestors' arrival and settlement on this continent. Coming to terms with this legacy is both a personal and civic project: to propose a method for Canadians, as members of an intergenerational polity, to participate in a necessary societal reckoning for colonial politics.

To do so, I first examined the purpose of the IAP, then expanded outward to look at the other aspects of the IRSAA. I needed to understand how the IAP, and through that process, Canadian law, conceived of "harm." Often the harm IAP claimants spoke about most strongly during IAP hearings were not the harms the 
process was designed to remedy. As discussed in previous work, I identified six categories of harms: 1) Sexual Abuse, 2) Physical Abuse, 3) Inadequate Care, 4) Emotional Abuse, 5) Cultural Harms, and 6) Inadequate Education. ${ }^{3}$ While fluid, these categories became a useful tool in conceptualizing harm and to assess the adequacy of government reparations.

From there I identified multiple reparations that were directly or indirectly related to the IRS policy. I noted several types of mechanisms for accountability that Canadian society has superimposed on the IRS policy to enable us to analyze the actions of individual and institutional wrongdoers, and to assess and compensate harms. I described how a narrow framing of harms in our legal dispute resolution mechanisms restricted the recognition of the types of harms experienced by IRS survivors. ${ }^{4}$ In order to address the unrecognized harms, I identified concepts of responsibility outside of legal processes that capture our attention in repairing wrongs. In particular, I proposed a broad application of the concept of intergenerationality that could be applied to the IRS legacy (and colonialism as a whole) to facilitate recognition of additional harms and engage present-day Canadians in their responsibilities in the IRS legacy.

In this article I advance that work by identifying thirteen responses (and a nascent fourteenth) that have been applied to the IRS legacy to date by the Canadian government, and by analyzing the types of harms and the concept of responsibility embedded within those reparations. I end this two-part project with a discussion of the things that we, as Canadians, can do to recognize harms and engage with our responsibilities for the IRS legacy.

I have made the practical decision to limit the discussion in this article to reparations that are directly tied to the IRS legacy. This separation is artificial. The IRS system was one aspect of a broader colonial project that caused many interrelated harms. The separation is required in order to create a manageable case study against which to analyze the legal and political mechanisms available to provide reparations for harms. Using the IRS policy also allows me to use my experience working in the IAP hearings in the Yukon as a touchstone for the entire project.

\section{Mechanisms of Responsibility}

Thirteen reparations have been provided to date by the Canadian state for harms stemming from the IRS policy. In setting them out I have two goals: the first is to demonstrate how many, and how many different types, of reparations have been applied already. My second purpose is to highlight the harms that have, and have not, been targeted through these many reparations. I conclude that we need a new lens, and new language, in order to address the harms caused by the IRS policy. 
Because my project is to examine Euro-Canadian laws and their purposes and results as applied by the Canadian government, I do not consider the application of Indigenous laws or processes outside of certain attempts by the government to work in a cross-cultural fashion. Furthering our understanding of how existing reparations are framed through Euro-Canadian laws, will, I hope, provide a base from which to engage with Indigenous approaches to harms and reparations.

The reparations applied to date are: i) criminal prosecutions, ii) the settlement of civil litigation, iii) Chapter Ten of the Report of the Royal Commission on Aboriginal Peoples, iv) the creation of the Aboriginal Healing Foundation, v) the 1998 Statement of Reconciliation, vi) the 12 Indian Residential Schools Resolution pilot projects, vii) the Alternative Dispute Resolution Program, viii) funding for commemoration, ix) funding for healing, $x$ ) the Common Experience Payment, xi) the Independent Assessment Process, xii) the Truth and Reconciliation Commission of Canada, and xiii) the 2008 Apology. A nascent fourteenth reparation is also mentioned: support for Indigenous institutions. Each is examined below.

\section{A. Criminal Prosecutions (1940s-present)}

Criminal prosecutions are a corrective justice mechanism that seek to identify individual wrongdoers based on harms set out in a criminal code. In the case of the IRS legacy, the harms recognized have largely been those of physical and sexual assault.

Victims of sexual abuse at IRSs have made complaints to the police and several perpetrators have been prosecuted. While the prosecution of sexual offenders did not gather steam until the 1980s when a group of survivors from the Yukon and British Columbia took action setting off a chain of police investigations and prosecutions, ${ }^{5}$ there were investigations as early as the 1940s. Among the few reported and investigated incidents are those at the Carcross IRS in Yukon in $1943^{6}$ and $1958,{ }^{7}$ at the Gordon IRS in Saskatchewan in 1947, ${ }^{8}$ and an investigation at the Williams Lake IRS that uncovered evidence of widespread abuse. $^{9}$

Several priests and employees subsequently pleaded guilty to charges of sexual abuse, being held to the most rigorous standard of individual responsibility. ${ }^{10}$ For example, in 1995 one former employee pleaded guilty to eighteen counts of indecent assault during his employment at the Port Alberni IRS and was sentenced to eleven years in prison. ${ }^{11}$ That same year another former employee was convicted and sentenced to sixteen years in prison on several counts of indecent assault, buggery, and gross indecency occurring while he was employed at the Lower Post IRS. ${ }^{12}$ Prosecutions continue to be pursued by victims and police today. ${ }^{13}$ 
It is important to remember that no single actor operates the criminal justice system. While the legislature defines crime, and prosecutors prosecute offenders, the initial step in a prosecution is a police investigation. In 2011, in recognition of its role in the IRS system, both in taking children to the schools and in failing to discover and investigate incidents of sexual abuse, the Royal Canadian Mounted Police published a study finding that, prior to the 1990s, there were very few police investigations of sexual abuse at residential schools. ${ }^{14}$

\section{B. Civil Litigation and Settlement (1990s-present)}

Civil litigation is another mechanism of corrective justice but one that is determined through case law, which bends and shifts over time though is still largely limited to recognizing physical harms caused. However, tort law has recognized a larger sphere of wrongdoers, including the possibility of employers and funders being found responsible through vicarious liability, and so it has been an important driver in the movement for reparations.

For example, the 1998 Statement of Reconciliation came just after a set of civil suits was filed by 200 survivors. ${ }^{15}$ Despite the difficulties in proving claims and the high costs, many survivors choose to seek redress through tort law, perhaps because of the perceived legitimacy of the judicial system and its public nature, which ensures that the harms of the IRS policy are widely recognized. ${ }^{16}$ The rules of procedure in civil courts also help even the power imbalance between survivors and the government. ${ }^{17}$ That said, the courts are not designed to handle large volumes of cases. As noted by the Yukon Supreme Court, "Simply put, our court system is not designed to accommodate such a large number of claims in a timely manner, ${ }^{18}$ making the use of class or representative actions necessary.

Litigation, including significant participation from northern survivors and their counsel, spurred the government to enter into negotiations for a settlement in the early 2000s. The resulting IRSSA can be interpreted cynically as the government avoiding a potentially much larger order for damages, but it can also be seen as an acceptance of responsibility for both the IRS policy itself, and for a reparations program. The parties to the political agreement agreed to seek certification as a national class action lawsuit folding in all outstanding actions by survivors of federally funded schools. In order to do so, approval and certification of the class actions was required, and obtained, by courts across Canada. ${ }^{19}$ The individual elements of the settlement will be addressed below.

\section{The Royal Commission on Aboriginal Peoples (1991-1996)}

Commissions of inquiry like the Royal Commission on Aboriginal Peoples (RCAP) or the Truth and Reconciliation Commission of Canada (TRC) are 
examples of transitional justice mechanisms through which a society moves from an authoritarian regime or state of conflict to one governed by the rule of law and a stable government. ${ }^{20}$ While truth commissions can vary widely in scope and powers, ${ }^{21}$ from simple collection of information and reporting to the ability to support prosecutions, they are usually free from the evidentiary and procedural restraints of criminal and civil courtrooms, and are often specifically tasked with "[r] ecognising and validating the pain and suffering of survivors and their families," ${ }^{22}$ which is only an ancillary purpose, if acknowledged at all, in civil and criminal processes.

RCAP was the first comprehensive study of the relationship between Canada and Indigenous peoples. Established by Order-in-Council, ${ }^{23}$ the RCAP was given a mandate to:

... investigate the evolution of the relationship among aboriginal peoples (Indian, Inuit and Métis), the Canadian government, and Canadian society as a whole. It should propose specific solutions, rooted in domestic and international experience, to the problems which have plagued those relationships and which confront aboriginal peoples today. The Commission should examine all issues which it deems to be relevant to any or all of the aboriginal peoples of Canada ... ${ }^{24}$

The RCAP held hearings across the country before making its final report and recommendations in 1996. In Chapter Ten of Volume 1 of its fivevolume report, the commissioners set out in detailed and blunt language the policy of assimilation that fuelled the IRS policy, ${ }^{25}$ the inadequacy of the education provided, ${ }^{26}$ the systemic neglect of children caused by financial and administrative shortcomings of the schools ${ }^{27}$ including the history of disease, ${ }^{28}$ shortages of nutritious food, ${ }^{29}$ harsh discipline, ${ }^{30}$ the sexual abuse of students and the knowledge of that abuse by administrators and other state actors. ${ }^{31}$ By naming harms beyond specific incidents of sexual abuse, the RCAP generated a broader knowledge of the harms caused by the IRS system and had the potential to spur a transformation of the Crown-Aboriginal relationship in Canada.

Chapter Ten ended with recommendations that the government establish a public inquiry to investigate the origins of the IRS policy and its effects, conduct public hearings, identify and investigate abuse at the schools, and recommend remedial actions including apologies, compensation, and funding for treatment of those affected, ${ }^{32}$ and to fund a national repository of records related to the IRS policy in order to facilitate access to the information, fund the collection of further testimony, work with educators to design curriculum about the schools, and conduct public education programming. ${ }^{33}$ 
The government's reply to the report in 1997, entitled "Gathering Strength: Canada's Aboriginal Action Plan," opened with a "Statement of Reconciliation" and plans for an Aboriginal Health Institute, as discussed below.

\section{The 1998 Statement of Reconciliation}

Political apologies are another mechanism of transitional justice that have increasingly been applied in Canada. While apologies vary widely in scope, there is a possibility for government apologies to exceed the limits of criminal codes and recognized torts to acknowledge responsibility, on behalf of an entire society, for a wide range of harms. ${ }^{34}$

On January 7, 1998, at a lunch-time meeting with five First Nations leaders, preceded by performances by Indigenous singers and dancers, ${ }^{35}$ then Indian Affairs Minister Jane Stewart delivered the previously published "Statement of Reconciliation," which included a specific apology for the IRS legacy:

One aspect of our relationship with Aboriginal people over this period that requires particular attention is the Residential School system. This system separated many children from their families and communities and prevented them from speaking their own languages and from learning about their heritage and cultures. In the worst cases, it left legacies of personal pain and distress that continue to reverberate in Aboriginal communities to this day. Tragically, some children were the victims of physical and sexual abuse.

The Government of Canada acknowledges the role it played in the development and administration of these schools. Particularly to those individuals who experienced the tragedy of sexual and physical abuse at residential schools, and who have carried this burden believing that in some way they must be responsible, we wish to emphasize that what you experienced was not your fault and should never have happened. To those of you who suffered this tragedy at residential schools, we are deeply sorry.

In dealing with the legacies of the Residential School system, the Government of Canada proposes to work with First Nations, Inuit and Métis people, the Churches and other interested parties to resolve the longstanding issues that must be addressed. We need to work together on a healing strategy to assist individuals and communities in dealing with the consequences of this sad era of our history. ${ }^{36}$ 
While the Statement acknowledged a broad range of harms, including separation of children and families, prevention of passing on language and culture, and the government's responsibility for the IRS system, the apology contained at the end of the second paragraph is specifically directed at the sexual and physical abuse suffered. In so doing the Statement identified the sexual and physical abuse suffered as the primary harm caused by the IRS policy to the exclusion of other harms. ${ }^{37}$ The Statement also limited the government's involvement as a wrongdoer to "the development and administration of these schools." It did not recognize the policy of assimilation that was the root of the IRS system. Nevertheless, by issuing the Statement the government was taking some responsibility for the recognition of a past harmful policy and the present needs of survivors.

The Statement was criticized on substantive and procedural grounds. Jeff Corntassel and Cindy Holder note that the Statement was carefully worded in "nondescript and guarded language" and sought to "close the book" on the IRS policy, for example by using wording that does not identify specific decisions or consequences. ${ }^{38}$ Matt James termed the Statement a "quasi-apology" because of its vagueness, improper ceremony in its delivery, and the inadequacy of the reparations attached to it. Specifically, the Statement was delivered at a lunchtime ceremony by a minister without the prime minister in attendance, does not form part of the state's parliamentary or legal record, and while it was offered "on behalf of all Canadians," it did not describe the wrongful acts or identify what institutions or policies were responsible for the harms. ${ }^{39}$ It also omitted the assimilationist goals of the IRS policy and its lasting effects. ${ }^{40}$ In her critique, Paulette Regan noted the absence of ceremony, crucial for setting the tone for the future relationship between Canadians and First Nations and in ensuring a meaningful apology. ${ }^{41}$ In the end, the Statement was a superficial acceptance of responsibility that "did not succeed in transforming existing colonial relationships with indigenous peoples." ${ }^{42}$

\section{E. The Aboriginal Healing Foundation (1998-2014)}

Reparations are sometimes provided in recognition of a harm outside of any legal definition, and without specific attribution of a cause or wrongdoer. For example, in its "Gathering Strength" document, the Government proposed the creation of what became the Aboriginal Healing Foundation (AHF) ${ }^{43}$ The AHF was created in 1998 "for the purpose of funding Eligible Recipients for Eligible Projects to address the healing needs of Aboriginal People affected by the Legacy of Physical and Sexual Abuse in Residential Schools, including the intergenerational impacts. ${ }^{" 44}$ It was provided with an initial endowment of $\$ 350$ million (plus another $\$ 165$ million in further endowments) ${ }^{45}$ and an eleven-year mandate (to March 2009). Through its funding of the AHF the government again accepted 
some responsibility for the reparation of harms stemming from the IRS policy, though not necessarily for the commission of those harms.

The AHF interpreted its mandate broadly to include all effects of the IRS policy:

Our vision is of all who are affected by the legacy of physical, sexual, mental, cultural, and spiritual abuses in the Indian residential schools having addressed, in a comprehensive and meaningful way, unresolved trauma, putting to an end the intergenerational cycles of abuse, achieving reconciliation in the full range of relationships, and enhancing their capacity as individuals, families, communities, nations, and peoples to sustain their well-being. ${ }^{46}$

The AHF was a body that sought to restore the integrity and health of individuals and, through them, communities. The AHF focused on the therapeutic response, so while non-Indigenous scholars and citizens offered research, opinions, and writing to its work, their contributions were largely focused on the victims' needs, not their own responsibilities. ${ }^{47}$

In addition to over 1,300 grants, including for twelve regional healing centres, ${ }^{48}$ and the administration and monitoring of projects, ${ }^{49}$ the AHF published more than twenty studies as well as compendiums of its research and a three-volume final report. The publications included quantitative research on the impacts of the Common Experience Payment on recipients; domestic violence, elder abuse, and suicide in First Nations communities; as well as several volumes of essays on the process of reconciliation in Canada. ${ }^{50}$ The AHF also funded and published projects about decolonization, cultural diversity, and reconciliation that were not limited to sexual abuse. ${ }^{51}$ In doing so it assisted in bringing to light a broader range of harms linked to the IRS policy.

The decision to end the AHF's funding was not well received ${ }^{52}$ and no new funding has been forthcoming despite a recommendation in the TRC's Interim Report that the government restore funding. ${ }^{53}$ The AHF wound down in September 2014.

\section{F. The Pilot Projects (1998-2004)}

Several reparations have been provided that stay within the bounds of established torts, while bending procedural rules to accommodate different cultural norms and relaxed rules of evidence. These include the pilot projects (and, as discussed below, the Alternative Dispute Resolution Program, and the IAP). 
The pilot projects were the result of eight exploratory dialogues on alternative dispute resolution carried out in 1998-99 in further response to the RCAP report. The result of the dialogues was a set of guiding principles, ${ }^{54}$ which included concern for the participants: that their participation be inclusive, safe, involve the community, and be based on mutual respect; for the process itself: that it be fair, holistic, voluntary, and consensus based; and for the outcome: that it produce fair results, appropriate remedies, and make appropriate linkages with other programs..$^{55}$

Twenty-seven projects were eventually authorized ${ }^{56}$ though only ten went forward. The pilot projects varied greatly ${ }^{57}$ but each involved a type of validation process for claims determined through negotiation. A preliminary report described the purpose and design of the pilot projects as follows:

In the end, however, the projects are geared toward discharging legal liability for abuse claims, albeit through a less formal and legalistic process than litigation. Thus, while there is scope for creativity with respect to process and settlement design, claims must ultimately be validated and compensation is only payable where, in the view of Crown legal counsel, liability has been established. In addition, because they are required to achieve legal closure, settlements must release the Crown (and the relevant church organization if it is participating in the settlement) from any future actions related to survivors' residential schools experience. $^{58}$

Among the non-discretionary elements of the pilot projects was the noncompensation for loss of language and culture. ${ }^{59}$

One project, the Hazelton apology feast, is documented in Paulette Regan's book Unsettling the Settler Within in which she details her involvement in the Hazelton pilot project. At the time, twenty-five individuals had worked through their legal claim but felt the process was not complete and so requested a feast be held. ${ }^{60}$ Regan described the apology feast as "an act of moral imagination":

That is, the Gitxsan connected the cultural loss experienced by IRS survivors to a powerful reclaiming of history, culture, family, community, and nation in a way that also brought Canada and the United Church into the feast hall—as hosts, with particular responsibilities to fulfill. ${ }^{61}$

A feast was chosen because it "provides a legal and political mechanism for addressing acts of wrongdoing by making public restitution and apology before 
all those assembled." ${ }^{62}$ Regan came to understand through her participation "how such highly structured ritual performances provide a safe environment for participants to process difficult feelings while also attending to future relations by creating mutual and ongoing social obligations." ${ }^{63}$

All aspects of the Hazelton feast, especially the deviations from standard Gitxsan protocols, were negotiated, ${ }^{64}$ a process that required a high level of involvement of all parties and of their acceptance of both the process itself and of their responsibilities within it. Prior to the feast, the hosts, Regan included, apologized to the Elders of each participating Gitxsan community and asked permission to host a feast as part of the invitation to the feast ceremony. ${ }^{65}$ During the feast, specific apologies were made and became part of Gitxsan oral history. ${ }^{66}$ In its apology the government accepted responsibility for the IRS policy, including "the harmful impacts of past assimilationist policies," and it also made a commitment to end racism. ${ }^{67}$

But while the feast became part of Gitxsan oral history, it might not have become part of Canadian history had Regan herself not chosen to write about it. It took her desire to take on the responsibility, as a beneficiary of government policies, to bring the feast to the public's attention.

As Regan noted, the pilot projects were limited by the litigation and tortbased approach, ${ }^{68}$ but also provided "the scope necessary for developing innovative, creative non-monetary compensation." ${ }^{69}$ The preliminary report also commented that the "inability to provide a meaningful response to language and culture loss has created a significant impediment to progress in the projects. ${ }^{\text {"0 }}$ Ultimately the government implemented a different mechanism to resolve claims that bore little resemblance to the pilot projects. ${ }^{71}$

\section{G. The Alternative Dispute Resolution Program (2002-2010)}

The Alternative Dispute Resolution Program (ADRP) was unilaterally created by the federal government in 2002,72 and was managed by an Adjudication Secretariat and an independent Chief Adjudicator. ${ }^{73}$ It was a tort-based approach to harms: individual survivors who suffered sexual abuse committed by an employee of an IRS were eligible for compensation after a hearing with an adjudicator who determined an award. ${ }^{74}$ Cultural loss was not included in the program ${ }^{75}$ nor was loss of income, though loss of opportunity was included to recognize un- or under-employment stemming from abuse. ${ }^{76}$ The major benefit of the ADRP was that liability was "taken as admitted," relieving the claimants of the burden of establishing a duty of care and breach of the standard of care by the government and churches ${ }^{77}$ once they had established damage and causation. 
The ADRP had two streams: Process A, which is described below; and Process B, a simplified process for claims of physical abuse or forcible confinement. ${ }^{78}$ In Process A the compensable "Acts Proven," "Consequential Harms," and "Consequential Loss of Opportunity" were set out in a grid with points assigned to different levels within the categories. The acts, harms, and loss of opportunity had to be proven on a balance of probabilities, but the causal link between the acts and the harms and loss of opportunity required only a plausible link. The claimant bore the burden of proof using relaxed rules of evidence. ${ }^{79}$ The points awarded for the acts and harms could be increased by $5-15 \%$ due to aggravating factors. The adjudicator awarded points based on the evidence of the claimant at the hearing. She then added up the points, which correlated to a dollar amount. Finally, an additional $\$ 10,000$ could be awarded for "Future Care" (or up to $\$ 15,000$ for psychiatric treatment) upon presentation of a future care plan. The award became a contract between the parties, which released the government from civil liability for the claim. The ADRP hearing would end with a "general apology" from the government representative to acknowledge the suffering caused by the IRS system generally. ${ }^{80}$

The alleged perpetrator was contacted and was given the opportunity to submit a witness statement and have a hearing with the adjudicator to respond to the claim. The alleged perpetrator was not a party to the ADRP and no finding of guilt or liability could be made. ${ }^{81}$

Chief Adjudicator Ted Hughes stated that the keys to the ADRP were its non-adversarial nature and the ability of adjudicators to question the claimant in a sensitive and relaxed manner. He noted that adjudicators held hearings in hospitals, on reserve, and in public facilities in order to allow the claimants to feel as relaxed as possible when telling a painful story. ${ }^{82}$ The ADRP was intended to be a "less adversarial, more cost-effective, and faster approach to resolving residential schools claims than litigation that would also support reconciliation." 83

While it was recognized as being better than litigation, the ADRP was heavily criticized. ${ }^{84}$ The Canadian Bar Association and the Assembly of First Nations (AFN) both provided detailed reports on the process that were studied by the House of Commons Standing Committee on Aboriginal Affairs and Northern Development. The AFN noted that while "[n]umerous, cumulative and complex harms" were caused by the IRS policy, Canada only acknowledged responsibility "for a narrow band of personal injuries" in the ADRP. ${ }^{85}$ The legal concept of responsibility - liability, fault, and causation included - featured prominently in the AFN's recommendations on how to modify the ADRP. Specifically, the AFN recommended that a new process include a presumption of fault and causation (once the claimant has proven the acts and harms). ${ }^{86}$ 
The ADRP, and the IAP discussed below, can be seen in two lights. In the first, the government sought to limit its liability to a narrow set of harms and created a process entirely for that purpose. In the second interpretation, while only a subset of harms were recognized, the government took on the responsibility of recognizing that harm had been caused and of providing reparations to survivors. Regardless of which interpretation wins out, the ADRP was a replication of "colonial power relations" in which the government controlled the scope of the claims accepted and the design of the process. ${ }^{87}$ As Regan writes, "the broad systemic injustices and harms created by the residential school policy and system demanded a deeper moral response from Canadian society than the program could deliver," ${ }^{88}$ or, as I argue, than the tort law paradigm through which the ADRP was conceived could comprehend.

After hearing testimony from survivors the committee recommended that the program be terminated and that the government undertake negotiations with survivors for a court-approved and court-supervised settlement of claims stemming from the IRS policy. ${ }^{89}$ In May 2005 the government entered into an agreement with the AFN to appoint former Supreme Court of Canada Justice Frank Iacobucci to consult with all parties and recommend a new settlement package for survivors. ${ }^{90}$ The resulting process, the 1.9 billion dollar IRSSA, has five components: funding for healing, funding for commemoration, the Common Experience Payment, the Independent Assessment Process, and the Truth and Reconciliation Commission of Canada. Each is discussed in turn below.

\section{H. The IRSSA: Funding for Healing (2007-2014)}

Without explicitly limiting the harms that could be recognized, the IRSSA provided a further $\$ 125$ million endowment ${ }^{91}$ for healing purposes, extending the AHF's mandate to September 2014..$^{92}$

The funding agreement explicitly recognizes that the IRS policy caused intergenerational harms and pinpoints "early detection and prevention of the intergenerational impacts of physical and sexual abuse" as one means by which the AHF is to fulfill its mandate. ${ }^{93}$ While not limiting the AHF's activities to healing for physical and sexual abuse, the enumeration of abuse and the absence of any other specific examples of harm in the funding agreement indicates that these specific abuses are still understood to be the predominant harms of the IRS policy for which the government has taken responsibility to repair.

\section{The IRSSA: Funding for Commemoration (2008-2015)}

Another tool of transitional justice is commemoration, which can take many forms (e.g., radio shows, ballets, plaques, statues) and holds great potential to draw 
the creators and the observers into dialogue. ${ }^{94}$ Because of the necessary personal engagement, acts and displays of commemoration potentially recognize a broad range of harms and could draw in a large number of perpetrators and beneficiaries whether directly or by intimation.

Twenty million dollars were provided in the IRSSA for "commemoration funding." ${ }^{95}$ The funding was geared towards "honouring, educating, remembering, memorializing, and/or paying respects to residential school former students, their families and their communities, and acknowledging their experiences and the broad systemic impacts of the residential school system." ${ }^{16}$ The commemoration funding was administered by the TRC, which accepted and evaluated proposals from "all former students, their families, communities and groups" and could include both regional and national projects, and projects geared towards both intra-family/intra-community and Indigenous-non-Indigenous relationships. ${ }^{97}$ Projects funded include film festivals, workshops, art installations and exhibits, parks, monuments, a story collection, and a ballet performance. In the North, funded projects included a ten-day Inuit Qaujimajatuqangit Cultural Camp in 2012, a healing totem pole in Whitehorse, and a drum dance workshop in Tuktoyaktuk. ${ }^{98}$

The objectives of the Commemoration Policy Directive, Schedule J of the IRSSA, included "honouring and validating the healing and reconciliation of former students and their families," contributing to "a sense of identity, unity and belonging," and promoting "Aboriginal languages, cultures, and traditional spiritual values," without any specific mention of abuse or other limiting statement as to the harms being commemorated. While the government provided the funding, the responsibility to engage in commemorative practices, through the fund, lies with survivors.

The government undertook its own act of commemoration by commissioning a stained glass window in Parliament commemorating the IRS legacy and the government's apology. ${ }^{99}$

\section{J. The IRSSA: The Common Experience Payment (2007-present)}

An example of an ADR mechanism that need not be bound by definition of crime or tort is the provision of ex gratia payments. These voluntary payments by the state also recognize, though not always expressly, that the state has a responsibility to remedy the situation. ${ }^{100}$

The CEP was a one-time payment to all IRS survivors based on years of attendance. Each applicant received $\$ 10,000$ for the first year or part thereof they attended an IRS, and $\$ 3,000$ for every year or part thereof they attended thereafter. ${ }^{101}$ 
The CEP was administered through a trust fund of 1.9 billion dollars established through Schedule I of the IRSSA. ${ }^{102}$ The excess in the fund was distributed pro rata to all recipients as education credits up to the amount of $\$ 3,000 .{ }^{103}$ Any excess funds after education credits have been distributed will be given to the National Indian Brotherhood Trust Fund and to the Inuvialuit Education Foundation to be used for education programs. ${ }^{104}$ As of 31 March 2019, 105,530 applications had been received, and 103,236 had been processed with an average payment of $\$ 20,457 .{ }^{105}$

The IRSSA is silent on the purpose of the CEP. However, prior to the negotiation of the IRSSA, the AFN proposed a monetary payment to compensate survivors for loss of language and culture regardless of whether the survivor had suffered further abuses. ${ }^{106}$ The fact that the AFN was involved in the negotiations, and the fact that the CEP payments are structured exactly like the AFN proposal, imply that the purpose of the CEP is to recognize the cultural harms that the IRS policy caused to all survivors. A study of the CEP conducted for the AHF also stated that the compensation was "for the general loss of culture and language that resulted from a system that separated children from their families and communities and that operated under policies of civilization and assimilation." ${ }^{107}$

In certifying the class action and settlement for the Yukon, Justice Veale commented on exactly this ambiguity and the difficulty in merging cultural disputes (and the resulting harms) with the structure of the common law:

From a common law point of view, the Common Experience Payment is an extraordinary resolution to a complex political and cultural dispute. It is inconceivable that a court would provide a remedy that compensates all Indian Residential School survivors with a financial benefit without proof of loss, by simply proving that a survivor attended an Indian Residential School. That is not to say that survivors did not suffer loss of language and culture, but simply to acknowledge the unique aspect of the remedy which could only be granted in a political forum. ${ }^{108}$

Without any indication in the negotiated documents it cannot be said whether the government sees the harm being recognized as the broader cultural injustice or is merely recognizing that the applicants were put at risk for the torts recognized in Canadian law. That said, the CEP is an acceptance of some responsibility on the part of the government to address the IRS "experience," whether as a potential civil liability or as a social responsibility. This ambiguity is interesting as it avoids a direct admission of the broader harms of the IRS by the government, but also allows the CEP to be interpreted as compensation for loss of language, for example. 
A study of the impacts of the CEP on recipients concluded that the CEP had both positive and negative impacts on recipients, but that while there were more positive impacts than negative, the negative impacts were of a greater magnitude. ${ }^{109}$ Specifically, recipients found the process to be confusing, particularly the exclusion of certain schools, and emotionally challenging. ${ }^{110}$ The administrative burden of the process shifted responsibility for the reparation to the survivors. The study also found the effects of the payments to be destructive on the recipient and community. ${ }^{111}$ These experiences affected the recipients' decision to enter into the IAP and to participate in the TRC, ${ }^{112} \mathrm{a}$ decision which impacted the effectiveness of both processes.

\section{K. The IRSSA: The Independent Assessment Process (2007-present)}

The IAP is an adjudicative process administered by a chief adjudicator and adjudication secretariat with input from an oversight committee composed of representatives from all the parties to the IRSSA. The IAP is based on the ADRP but was modified through negotiation, ${ }^{113}$ and like the ADRP and pilot projects, is bounded by a tort law conception of harm and wrongdoers.

The IAP uses substantially the same model as the ADRP: categories of "Acts Proven," "Consequential Harms," and "Opportunity Loss" linked to a point scale; but it recognizes a broader range of acts and harms ${ }^{114}$ as well as compensates for physical abuses caused by fellow students. ${ }^{115}$ The IAP contains a "standard track," where most claims are resolved, and a "complex track" for claims of "Actual Income Loss" and "Other Wrongful Acts." The burden of proof in both tracks lies with the claimant. In both tracks the acts proven, consequential harms, and opportunity loss (actual income loss in the complex track) must be proven on a balance of probabilities. ${ }^{116}$ Causation is proven on the lesser "plausible link" standard in the standard track ${ }^{117}$ and on the more stringent "balance of probabilities" in the complex track. ${ }^{118}$ Only the harms and opportunity loss that are linked to the acts, either by the claimant's evidence or expert evidence, are compensable in the IAP. ${ }^{119}$ The points awarded for acts and harms may be increased by $5-15 \%$ for aggravating factors and a further $\$ 10,000$ or $\$ 15,000$ may be awarded for counselling or psychiatric treatment based on the claimant's future care plan.

The conduct of an IAP hearing is essentially the same as an ADRP hearing, including provisions for the alleged perpetrator to provide a statement and have a hearing. While not written in the model, the IAP also includes an "acknowledgment" where the individual acting as Canada's Representative at each hearing acknowledges the claimant's courage in participating in the process and the harmful effects of the IRS policy on the survivor. The claimant is also offered a personalized letter of apology from the government with the final paperwork. 
The IAP is based on the tort law system of individual victims and perpetrators. As in the ADRP, the vicarious liability of the government is taken as a given though not expressly stated. The harms recognized must all be connected to a category of sexual or severe physical abuses. Any consequential harms that cannot be linked to those compensable acts, even if linked to the experience of attending an IRS, are not compensable. The process, however, takes restorative justice concerns into account through the culturally sensitive "inquisitorial" method of eliciting evidence, the flexibility in hearing location, availability of health support, and in the acknowledgement that addresses the relationship between the claimant and the government.

As of 31 March 2019, 38,257 applications had been received and 38,178 $(99 \%)^{120}$ had been resolved with an average payout of $\$ 111,265$ (including legal costs). ${ }^{121}$ Responsibility in the IAP is first and foremost the legal liability stemming from vicarious liability for the actions of IRS employees. However, my own experience was that the individuals acting within the IAP could reframe the process, ever so slightly, to address a deeper responsibility between citizens not found in the model. Whether acting as Canada's Representative, the adjudicator, or claimant's counsel, participants chose to avoid adversarial conduct, focused throughout the hearing on the well-being of the claimant, and ended the day with expressions of both official and personal acknowledgement of the claimant's experience, harm, and strengths, and well as hope for a shared future.

\section{The IRSSA: The Truth and Reconciliation Commission of Canada (2008-2015)}

A second example of a broad public commission of inquiry, and the clearest application of transitional justice in Canada, the Truth and Reconciliation Commission of Canada (TRC) is also the only truth commission to date to be the product of a court process ${ }^{122}$ and was, in important ways, bounded by that tort-based framing of harms and wrongdoers.

The TRC had a five-year mandate and a budget of $\$ 60$ million $^{123}$ to address the "IRS legacy," as set out in Schedule N of the IRSSA:

There is an emerging and compelling desire to put the events of the past behind us so that we can work towards a stronger and healthier future. The truth telling and reconciliation process as part of an overall holistic and comprehensive response to the Indian Residential School legacy is a sincere indication and acknowledgement of the injustices and harms experienced by Aboriginal people and the need for continued healing. This is a profound commitment to establishing new relationships 
embedded in mutual recognition and respect that will forge a brighter future. The truth of our common experiences will help set our spirits free and pave the way to reconciliation. ${ }^{124}$

The specific goals set out in the mandate included to "acknowledge Residential School experiences, impacts and consequences" ${ }^{25}$; "promote awareness and public education of Canadians about the IRS system and its impacts" ${ }^{126}$; and to produce a report with recommendations "concerning the IRS system and experience including: the history, purpose, operation and supervision of the IRS system, the effect and consequences of the IRS ... and the ongoing legacy of the residential schools." ${ }^{127}$ While the mandate was not limited to specific harms, the TRC was the product of a legal settlement, which was based on personal injury law and the embedded tort law approach to harms. ${ }^{128}$ Notably, its mandate focused on the IRS legacy, and was not meant to engage in the broader issues of colonialism, ${ }^{129}$ nor was it to evaluate the government's response to the IRS legacy. ${ }^{130}$ Nevertheless, the TRC took a broad view of its mandate, locating the IRS policy squarely within the history of colonization of North America, and took an equally broad view of the harms caused by the IRS policy.

The TRC was composed of three commissioners, Chairperson Justice (now Senator) Murray Sinclair and Commissioners Chief Wilton Littlechild and Dr. Marie Wilson, as well as a secretariat, executive director, and a staff of administrators, historians, and researchers. The TRC produced an interim report, ${ }^{131}$ a historical document entitled They Came for the Children; ${ }^{132}$ held seven national events (Winnipeg, Halifax, Inuvik, Saskatoon, Montreal, Vancouver, and Edmonton) as well as smaller community events across the country, including one in Whitehorse, and, finally, a voluminous six-volume final report containing ninety-four recommendations, in the form of Calls to Action. ${ }^{133}$

Participation in the TRC was voluntary. The TRC did not have the ability to act as a public inquiry and did not possess subpoena powers. ${ }^{134}$ It could not make recommendations about the criminal or civil liability of any person or organization ${ }^{135}$ or duplicate any legal proceedings. ${ }^{136}$ One of its tasks was to combat "widespread ignorance" of the IRS policy and legacy amongst nonIndigenous Canadians through public hearings and create "an incontrovertible historical record." 137

The TRC experienced several difficulties, including a false start when its three original commissioners resigned ${ }^{138}$ and a court battle with the government over the production of documents. ${ }^{139}$ In his resignation letter, original Chairperson Justice Harry LaForme identified a difference in opinion between himself and the original two commissioners as his primary reason for resigning. In his words: 
The reason is that they and their supporters see the TRC as primarily a truth commission. Unlike mine, theirs is a view that leaves much of the work of reconciliation for another day. It is a view that does not recognize the need for uncovering and recording the truths of the IRS past and legacy as but a part, however important, of the greater whole of reconciliation. ${ }^{140}$

The event highlights the challenges in framing a truth commission.

As an institution with a national mandate, the TRC had the potential to engage large swaths of Canadians with their role in the IRS legacy. The TRC spread the seven required national events across the country and held many smaller regional events so that large numbers of survivors and Canadians could participate easily. The TRC did not, however, capture the public imagination in the same way that other truth commissions have, ${ }^{141}$ apart, perhaps, from some late movement in the form of two marches, in Vancouver and Ottawa, parallel to TRC events in those cities. ${ }^{142}$ News coverage was sporadic and limited to reports of the court battles or immediately surrounding the national events. The TRC did not achieve a broad engagement of the non-Indigenous population in its activities, which is a key element in transitional justice. ${ }^{143}$ It was also criticized for focusing too much on truth and not enough on reconciliation, ${ }^{144}$ echoing the concerns of Justice LaForme, thus possibly limiting its ability to improve relationships between Canadians, generally, and survivors.

Issued in December 2015, the TRC's final report consists of a six-volume document detailing the genesis of the IRS policy and the operation of the schools, specific experiences of Métis students and the Inuit and Northern Experience, a dedicated study of missing children and unmarked burials, as well as volumes dedicated to expressing the legacy of harm stemming from the IRS policy, and potential avenues for reconciliation. In issuing separate volumes the TRC was able to validate the different effects the IRS policy had on the North, for example the dramatic migration of Inuit families from their traditional lands to cities in order to stay close to their children in hostels/schools. ${ }^{145}$

Along with its significant historical reporting, the TRC's ninety-four Calls to Action target various aspects of Canadian society including federal and provincial governments, all levels of the education system, media outlets, sports organizations, the legal profession, the child welfare system, and the health system. The stated goals of the Calls to Action are to "redress the legacy of residential schools and advance the process of Canadian reconciliation." ${ }^{146}$ Significantly, the TRC endorsed a broad concept of "reconciliation," one that is to be brought into being using multiple mechanisms including "repairing damaged trust by making 
apologies, providing individual and collective reparations, and following through with concrete actions that demonstrate real societal change." ${ }^{147}$

While Indigenous processes are outside of the scope of this article, it is important to note that the TRC identified the revitalization of Indigenous laws and legal traditions as key to the work of reconciliation: "If Canada is to transform its relationship with Aboriginal peoples, Canadians must understand and respect First Nations, Inuit, and Métis peoples' own concepts of reconciliation. Many of these concepts are found in Indigenous law." ${ }^{148}$ As will be discussed below, as part of the idea of "institutional support," Indigenous justice systems may contain further resources to repair the harms caused by the IRS policy.

The government accepted the TRC's final report in December 2015, with a promise to fully implement all ninety-four Calls to Action. ${ }^{149}$ Implementation is currently underway and is being tracked closely by federal officials ${ }^{150}$ and news organizations. ${ }^{151}$ It will likely be many years before Canadians are able to assess their governments', and their own, responses to the Calls to Action. As noted by Regan, "The reconciliation volume of the final report was not intended to be the final word on the subject; rather, it serves as a catalyst for ongoing public education, dialogue, and action at national, regional, and local levels."152

\section{The 2008 Statement of Apology}

The 2008 Statement of Apology may have expanded the recognition of harms and wrongdoers for the legacy. In contrast to the small and informal gathering in 1998 for the Statement of Reconciliation, hundreds of Indigenous people travelled to Ottawa on 11 June 2008 to watch the Apology on a large screen on Parliament Hill. There was a significant lead-up in the media and the Apology was televised live. Prime Minister Stephen Harper delivered the Apology in the House of Commons with five Indigenous leaders and six survivors in attendance. ${ }^{153}$

The Apology specifically stated that the policy of assimilation underlying the IRS system was wrong, recognizing that the policy itself caused harm and therefore the government that instituted it was a wrongdoer:

Two primary objectives of the Residential Schools system were to remove and isolate children from the influence of their homes, families, traditions and cultures, and to assimilate them into the dominant culture. These objectives were based on the assumption Aboriginal cultures and spiritual beliefs were inferior and unequal. Indeed, some sought, as it was infamously said, "to kill the Indian in the child." Today, we recognize that this policy of assimilation was wrong, has caused great harm, and has no place in our country. 
The government now recognizes that the consequences of the Indian Residential Schools policy were profoundly negative and that this policy has had a lasting and damaging impact on Aboriginal culture, heritage and language. ...

We now recognize that it was wrong to separate children from rich and vibrant cultures and traditions, that it created a void in many lives and communities, and we apologize for having done this. ... ${ }^{154}$

In a significant break from protocol, the guests, including Phil Fontaine, then Chief of the Assembly of First Nations and a lead plaintiff in the class action, were permitted to address Parliament from the floor of the House of Commons. ${ }^{155}$

While the 2008 Apology was better received than the 1998 Statement of Reconciliation, it has not been universally accepted, nor did it capture the public's imagination. ${ }^{156}$ Eva Mackey criticizes the omission of the words treaty, territory, and land ${ }^{157}$ from the text and for minimizing the extent of the wrongdoing to Indigenous peoples. ${ }^{158}$ The Apology was an apology for the IRS policy only, not for colonization. Mackey also criticizes the Apology for being unilateral, instead of dialogical, and Parliament and the media for assuming that the Apology would be accepted by Indigenous leaders. ${ }^{159}$ Indigenous leaders acknowledged it and listened to it but did not necessarily accept it. Many stated that they were waiting for action on a range of issues before accepting the apology. ${ }^{160}$ Nevertheless, in stating, "we apologize for having done this," the government accepted, in the clearest terms to date, responsibility for the acts that led to the harms caused by the IRS policy.

The breadth of the Apology has come into question in light of the findings of the TRC that medical ${ }^{161}$ and nutritional ${ }^{162}$ experiments were carried out on residents. While some have called for an apology specific to the experiments, ${ }^{163}$ the government of the day stated that the Apology covers everything that happened at the schools and did not issue a further apology. ${ }^{164}$ Subsequently there have been calls through statements, websites, and gatherings for the government to "Honour the Apology." 165

\section{N. (Institutional Support)}

It would be remiss not to also mention a nascent fourteenth reparation that, while not solely due to the IRS policy, certainly engages deeply with the harms it caused. This is a model that seeks to remedy harms through support for the (re)establishment of Indigenous institutions as recognition that harm was done to the structure of Indigenous societies. ${ }^{166}$ As noted above, the TRC identified the (re)building of Indigenous institutions, including systems of 
justice, as essential to understanding and applying Indigenous perspectives on reconciliation.

The primary example of government support for such rebuilding that can be linked directly to the IRS legacy is the Indigenous Languages Act, ${ }^{167}$ which responds to Calls to Action 14 and 15, and explicitly references the impact of Indian Residential Schools in a preambular clause. This Act establishes a Commissioner of Indigenous Languages whose mandate is, among other things, to support and strengthen Indigenous languages. In this way the Act moves towards reparation for the loss of language that is not recognized in Canadian criminal and tort law frameworks.

The Indigenous Languages Act was followed a few weeks later by the introduction of the Act respecting First Nations, Inuit and Métis children, youth and families, ${ }^{168}$ which also references the IRS legacy. This Act aims to affirm the jurisdiction of Indigenous governments in the field of child welfare, perhaps a recognition that the IRS policy caused harm to the relationships between parents and children. While both Acts may have important effects, we may need to wait many years before being able to assess their success.

Finally, the federal government has responded to Call to Action 50 by providing funding to institutes working on the revitalization of Indigenous laws, with additional funding expected to flow over the coming years. ${ }^{169}$

\section{Responsibility for Canada}

This survey of existing reparations has delineated the government's many efforts to address the harms of the IRS policy. Beginning with criminal prosecutions and moving through a series of ADR and transitional justice mechanisms culminating in the 2008 Apology, the Canadian government has sought to do justice, to discharge its liability, and to take responsibility, for many harms. Individual physical and sexual assaults have, to an extent, been recognized through criminal prosecutions. The federal government has recognized vicarious liability through the IRSSA. Elements of the IRSSA, notably the CEP and aspects of the IAP, have provided some (implicit) recognition for the racism experienced by survivors. Commemoration, in its various forms, has brought the IRS legacy closer to the surface for those Canadians interested in engaging. The TRC was able to explore physical and sexual abuse, loss of connection to parents and community, loss of language, and the lack of parenting skills affecting the children of survivors. There have also been two apologies that, to an extent, acknowledge the government itself as being the cause of harm.

It is a long list. One that recognizes many harms and many wrongdoers (whether explicitly or implicitly) within the confines of criminal and tort law as 
well as outside of them. As noted at the outset, each of these reparations is the product of a particular way of thinking about harms and about responsibility. So why isn't it enough?

In this final section, I attempt to answer that question by analyzing the ability of the thirteen established responses to both address the full range of harms stemming from the IRS policy and to engage Canadians in their responsibility as beneficiaries of the colonial endeavour that gave rise to the IRS policy. In doing so I draw heavily on concepts of responsibility that I explored in detail in previous work. ${ }^{170} \mathrm{I}$ continue to use the IRS policy in isolation from the reality of interrelated colonial policies as a starting point for what otherwise may seem too daunting a story.

\section{A. The Recent Past}

As a young lawyer and a new public servant working in the Yukon, I struggled with my role within the IAP because the stated goals of the process did not correspond to what I understood to be the needs of survivors, or to my own needs to connect with survivors and others about how the IRS legacy has affected all Canadians. The context of northern practice, where the day after I attended a particularly emotional IAP hearing I found myself volunteering at the curling club and waiting on that same survivor's table, meant that it was not possible to isolate one aspect of my life from another. The personal, the social, and the professional are often melded in smaller centres like Whitehorse. Perhaps it was this context, even more than any specific hearing, that led me to understand that this analysis is not about the IAP, or even about recognizing harm. It is about how Canadians, individually and as a society, understand our history, our place within it, and our relationships with each other.

If every person I had met outside or inside of the IAP had approved of the process I might have accepted the limitations of its tort law approach. Instead I faced conflict from people who felt like the IAP was too much of a remedy as well as from people who felt it was too little. The lack of a consistent understanding of the purpose of the IAP led me to wonder if my concerns were due less to the structure of the IAP or the remedy it provided, than with our lack of a collective understanding of what harm was being remedied and why it should be remedied at all. It was not until I began to examine my role as an actor within an intergenerational polity that I began to understand my discomfort with the IAP.

The many reparations provided to date have, even in aggregate, failed to adequately name, recognize, and respond to the full range of harms caused by the IRS policy, because they too often accept the limitations of the existing institutions, which have failed to develop a category of responsibility beyond those 
of criminal and tortfeasor that would draw non-Indigenous Canadians into the discussion of the IRS policy and allow us to recognize our own responsibility for systemic wrongdoing. Canadians reasonably cannot see themselves as guilty or liable for past harms. Without recognition of the responsibilities at the core of the IRS policy, Canadians will be content to rely on established Euro-Canadian legal categories of harm that fail to acknowledge the racism inherent in the IRS policy and the full range of harms it caused.

\section{Restatement of Harms}

As summarized above, I identified six categories of harms caused by the IRS policy: sexual abuse, physical abuse, inadequate care, emotional abuse, cultural harm, and inadequate education. ${ }^{171}$

My inquiry is inspired specifically by the descriptions of "cultural harm" I heard during IAP hearings that reflected so pointedly back onto recent losses in my own life. Considering those harms within the IAP, a process steeped in the principles of tort litigation, left me questioning the validity of an institution that ignored (at least formally) the harms I heard. It seemed to me that the failure to recognize cultural harm stemmed not from ignorance or dismissal of the experiences of survivors but from the inherent and largely unquestioned limitations of tort law. Because the legal framework in which I was working required the existence of an individual wrongdoer with a causal link to the harms, the harms I heard about in IAP hearings, which affected me so deeply, could not be recognized. Those harms were not caused by an individual but by a policy put in place by a government acting on the mistaken, and racist, presumptions that Indigenous peoples were an inferior and dying race-presumptions that were widely held by Canadians who either actively supported, or passively allowed, the IRS system to exist for a century and a half within the broader colonial project. An individual cannot be responsible for the loss of a language.

Stepping back from the IAP and looking at the reparations more broadly, I began to see a patchwork approach to recognizing harms that, while based on criminal and tort law, was also based on transitional justice and restorative justice principles. I now consider the IAP to be a fair and responsive process located within the tort law framework. This limitation is acceptable because it is not the sole response to the IRS legacy. My expectation of a single institution or process to handle all elements of the IRS legacy was unrealistic. There were too many players within the IRS system, and too wide a variety of harms stemming from it, for a single process to adequately address every wrongdoer and every harm simultaneously.

But just because one size cannot fit all does not mean that Canadians should limit our response to the harms of the IRS policy to those easily addressed by our 
most common dispute resolution mechanisms. The absence of a tort of "cultural harm" means that civil courts are not the appropriate mechanism to recognize loss of language. It does not mean that the harm does not exist or that we should not address it. Our failure to do so perpetuates the harm and does disservice to our own interests as Canadians.

\section{Restatement of Responsibilities}

The responsibility to redress harms extends more widely and is built on different foundations than the responsibility found in criminal and tort law. We have applied our standard institutions with their limited definitions of harm and their focus on individual and institutional perpetrators before considering whether they are capable of addressing the actual harms of the IRS policy. Canadians have inadequately theorized the concept of our responsibility as members of an intergenerational polity because Canadians have not yet been presented with a reason to consider our own responsibilities for the IRS legacy despite the proliferation of responses to date.

In previous work I articulated such a reason. I drew from several authors, notably Iris Marion Young, Paulette Regan, John Torpey, and Janna Thomson to employ their engagement with the responsibility of citizens in the social, legal, and political structures of a society. While no one person is to blame for structural injustices, not being legally liable should not absolve any citizen from contributing to an injurious structure. ${ }^{172}$ The language of "blame" is, in and of itself, a barrier to the recognition and acceptance of responsibility by citizens of injustices. Regan consequently suggests re-naming the parties as "descendants" and "beneficiaries," instead of "victims" and "perpetrators." 173 In these terms those within a polity who did not cause or carry out a harmful policy or program are not absent from the scene but are integral to it, as the intended beneficiaries of the policy. For Thompson, the legitimacy and continued survival of a polity is found in its acceptance of the responsibility to carry on the good projects of its forebears and to establish such projects for its descendants. If a previous generation failed to uphold the values the current generation espouses, it is up to that present generation to address those failures. ${ }^{174}$

Thus, if we are to consider ourselves to be the legitimate inheritors of our polity's achievements, to be proud Canadians, we also inherit their failures and a responsibility to rectify the harm done by our predecessors. This is a necessary foundation to adequate reparations for the IRS legacy. We are members of an intergenerational polity, one that has benefited from a policy—specifically the IRS policy within the broader colonial endeavour-that caused corresponding harm to some of our fellow citizens. It is from this basis that we must analyze the need for reparations. 


\section{Responding Reflexively}

I have inherited, either through the accident of my birth in small-town Northern Ontario, or through my active participation in social life, all the benefits of Canadian citizenship, from the right to vote, to access to health care and education, to the ability to live and work anywhere I choose. I have also inherited responsibilities for the harmful consequences of my government's decisions. The fact that my rights and freedoms stem from the same source as others' oppression requires recognition.

This understanding of our responsibility as Canadians for the effects of the IRS policy on present-day citizens forces us to start from a common understanding of our shared history — even if that means we need to re-write that history together to include recognition of the harms experienced by survivors and their families, as well as an understanding of the motives behind the IRS policy. It will include concepts of harm and responsibility drawn from Indigenous laws and cultures. The new history becomes a tool to explain responsibility to Canadians (whether uninformed or misinformed adults, children, or new immigrants) and the basis for a discussion of reparations.

As discussed above, the mechanisms applied to date have been framed largely through the Euro-Canadian legal theories of criminal guilt and civil liability. These reparations are adequate if the harms stemming from the IRS policy are understood solely as the physical and sexual abuse of students and a selection of consequential harms and loss of opportunity stemming from them. This approach is not wrong. But my experience listening to claimants describe the harms they experienced makes me certain that this approach is incomplete.

Consequently, I do not advocate reshaping our legal institutions to incorporate a broader range of harms. That project assumes that criminal prosecutions and civil liability are the best ways to recognize harm and assign responsibility. That analysis continues to assume that "responsibility" is confined to the concepts of guilt and liability while potentially, as Young argued, watering down the effectiveness of the criminal and civil processes when they are applied in those situations to which they are best suited..$^{175}$

The approach I advocate considers that we are all responsible through our status as intergenerational beneficiaries of the policies and actions of our political and social ancestors. Taking up the concept of responsibility means that we look at the facts set out in the TRC's detailed report with no preconceived notion of what categories of Canadians are victims or perpetrators. Just as we must rewrite our history in order to recognize the full range of harms caused by the IRS policy, we must allow for the full range of Canadians to bear some portion of the responsibility for responding to those harms today. In doing this we do away with 
any hierarchy among dispute resolution mechanisms and look at all of the available mechanisms as equally legitimate tools to respond to the variety of harms.

The possibility to respond to additional harms did exist within our present responses. The ambiguous purpose of the CEP, for example, can be held out as recognizing broader harms than those recognized in tort law and as a vindication of survivors' rights to maintain their language and culture. The decision to not provide an explicit statement of what "common experience" is being compensated, meant an opportunity was lost to expand recognized categories of harm and further the public debate over what the IRS "experience" represents to survivors and to Canadians generally. The TRC, while it adopted a broader concept of harm, did not break the mould of legal proceedings in its treatment of perpetrators. By focusing on the stories of survivors and the needs of survivors, their families, and communities (which may have been a necessary first step in a longer process), the TRC missed the opportunity to draw all Canadians into the discussion. While the TRC made some efforts to reach out to schools and to provide interpretive displays during its national events, these measures fell far short of engaging Canadians in a discussion of how they fit in the IRS legacy and what responsibility they may have to participate in the reparations.

Bearing witness to stories of harms outside of the narrow legal framework of Euro-Canadian legal theory and institutions forced me to consider responsibility differently, to rethink early Canadian history and to place myself within that legacy. But most Canadians have not had a similarly unsettling experience. Among those who have, each individual has reacted slightly differently. Consequently, no clear sense of how the history of contact, colonialism, and residential schooling connect to our present rights and responsibilities as Canadians has developed. Achieving that clarity is a prerequisite to understanding how to recognize and address our history, including the IRS policy. There are ways to harness our existing legal, political, and social institutions to engage all Canadians with both our history and our future as a polity. From that engagement a framework for our responsibilities should emerge and with it recognition of all the harms caused by the IRS policy.

\section{B. Engaging Canadians}

So, what to do about the strangers who so often passed through my life making snide remarks, or who ignored me on my soapbox, leaving me in alternating fits of guilt and rage? They, as much as the claimants' stories, or the title of Canada's Representative, were the catalyst for this project. I conclude this project with my suggestions for how we, as Canadians, might accept and begin to carry out our responsibility for the IRS legacy. 


\section{Apologies}

There have been two state apologies in Canada, but many Canadians, survivors included, are not aware of their contents. There are a few ways to make the 2008 Apology part of the public consciousness and spur further discussion. One would be to follow the TRC's recommendation to provide a framed copy of the apology to all schools in the country to be displayed prominently and taught as part of the curriculum. In this way the apology would become part of the general knowledge of students as they mature into decision makers in the Canadian polity. The second way for an apology to become part of the public discourse would be for Canadians to rally around it as a social movement as Australians did in 1998 when they began the tradition of "Sorry Day." In combination, these two measures would target youth and adults alike.

\section{Commemoration}

The funding for commemoration found within the IRSSA could potentially transform the Canadian landscape with the addition of plaques and monuments on the sites of former residential schools ${ }^{176}$ and fill our radios with documentaries about survivors. ${ }^{177}$ As the SCC found, "public commemoration of the residential schools system is also a core objective of the IRSSA." ${ }^{178}$ But most of the projects funded were focused internally to communities or schools and the families of survivors, not geared to creating awareness and involving non-Indigenous Canadians.

Commemoration, as a tool, could have a second phase, one that focuses on the non-Indigenous community to promote awareness, create empathy, and engage us in our responsibilities as citizens for our polity's history. Projects could be large or small, general or aimed as a specific community of Canadians (for example new immigrants or northerners) and use any method (plaques, ballet, graphic novels, theatre). The TRC identified several possibilities in Calls to Action 79 to 83. The more opportunities for involvement, the more likely Canadians will come across a survivor, a story, an image, a fact, that draws them into the IRS history, the way claimants'stories of lost family members did for me, prompting us to question our role within the IRS legacy.

\section{Education}

Education can be part of both institutional reform and commemoration and is an important tool to effect the switch from guilt to responsibility. Learning about the IRS policy, without added interpretation about its present-day effects, might allow Canadians to view the policy as the problem of past people for which they are not to blame and should bear no responsibility. Education about the IRS legacy 
must be crafted in a way that allows us to learn not just about the IRS legacy, but from it. ${ }^{179}$ Educators have this opportunity to engage their students in their responsibilities as Canadians for the IRS legacy without alienating them with the concepts of guilt and liability, but they must be given the tools with which to do it.

In its interim report the TRC recommended both public awareness campaigns and specific school curricula to educate Canadians about the IRS legacy. ${ }^{180}$ To carry out its own recommendation, the TRC built "education days" into its national events during which schools are invited to participate in a series of age-appropriate workshops about the history of the residential schools and Canadian history generally. A National Research Centre on Indian Residential Schools is housed at the University of Manitoba in Winnipeg. ${ }^{181}$ Several jurisdictions are developing mandatory programming on the IRS legacy. Northern jurisdictions have been at the forefront of this process, notably the Northwest Territories and Nunavut, which incorporated units on the IRS legacy into their high school curriculum in $2012^{182}$ as well as Alberta where curriculum has been developed for all grades from Kindergarten to Grade $12 .{ }^{183}$ Law schools have taken up the TRC's Call to Action 28 and have instituted additional courses, some optional, some mandatory, on Aboriginal Law and/or Indigenous legal traditions and have moved towards creating Indigenous Law institutes in response to Call to Action $50 .{ }^{184}$

\section{Storytelling}

Storytelling can occur in formal and informal settings and is an important tool for creating a joint narrative. ${ }^{185}$ The idea of storytelling as a mechanism of engagement and responsibility hits home with my experience in the IAP. The IAP, and the TRC, are essentially storytelling forums: the claimant's "story" is the evidence upon which an IAP settlement is based; through the TRC a public record of experiences of IRS survivors (and others) is being created. I am telling a story through this article of my own experience as a Canadian trying to come to terms with my country's history and my role within it. Storytelling has the potential, more than any formal mechanisms, to engage individuals on a large scale.

In her exploration of storytelling in Shattered Voices: Language, Violence, and the Work of Truth Commissions, Teresa Godwin Phelps argues that storytelling can provide "justice" to victims and to the social fabric of a country. Writing of benefits to the victims she states that "making stories of our lives is what we humans do. It is the fundamental means by which we assert and describe our humanity."186 It is also a means by which we can retrieve our humanity by exploring our roles in a racist policy. Storytelling as a mechanism for engagement "is an essentially human act that enables all of us to make sense of our lives and to feel integrated as 
members of a community." 187 By encouraging both survivors and perpetrators-or descendants and beneficiaries - to come forward and tell stories,

the country itself benefits from having better citizens, and the stories help bridge the chasm between the past, in which people were enemies to each other, and the present, in which former adversaries coexist as fellow citizens: the country before and the new country that is forever changed by the events of the past. ${ }^{188}$

Stories can break through the hegemony of the accepted national narrative and "capture and transmit common human emotions such as pain, loss, separation, desperation," ${ }^{189}$ creating empathy and drawing members of the dominant community into the story and into the process of revising it. Finding spaces for storytelling honours survivors and draws us together in the act of telling, listening, and coauthoring Canada's next chapter.

\section{5. (More) Institutional Support}

As noted above, a type of reparation that is gaining momentum is government support for the rebuilding of Indigenous institutions. While perhaps largely addressed in Canada through self-government negotiations, the rebuilding of Indigenous institutions, in particular justice systems, has been identified by both academics ${ }^{190}$ and the TRC as a form of reparation for the specific harms of the IRS policy. As the IRS policy affected multiple areas of Indigenous life, the TRC proposed changes to, or increased Indigenous control over, institutions touching on various areas including child welfare (CTA \#1), languages (CTA \#14), justice systems (CTA \#42), and laws (CTA \#50), for example.

Re-establishing Indigenous institutions may be a necessary pre-condition to other reparations, which will only be legitimate if understood and accepted through the lens of Indigenous peoples' own cultures and laws. ${ }^{191}$ The federal government has recently moved towards implementing a form of institutional reparation through the Indigenous Languages Act, the Act relating to First Nations, Inuit and Métis children, youth, and families, and funding for Indigenous law institutes. These Indigenous institutions, while aimed primarily at the Indigenous community, have the potential to engage non-Indigenous Canadians as well through increasing the space, for example, for Indigenous languages in the public sphere, or the application of Indigenous laws to interactions between Indigenous and non-Indigenous communities. 


\section{Canada's Representatives}

This project started because I took a job in Whitehorse that required me to attend IAP hearings. It was an opportunity I am grateful to have been given. I did not know then how deeply my time living and working in the North would affect my thinking about my profession and my country. I am not alone in this experience.

While many of the IRS reparations, like the IAP, happened in private, they were attended or carried out by people-individual lawyers, caseworkers, assistants, public servants, adjudicators, health support workers, and others. For many of us the experience was transformative, and these experiences will stay with us through the rest of our lives and inform our personal and professional interactions. While each of us will do so in accordance with our own beliefs and strengths, it is incumbent upon us to honour our experiences by interpreting them, as best we can, to our family, friends, and community. Through these interactions we might eventually reach all those Canadians who otherwise avoid engaging with the IRS legacy.

\section{Conclusion: Where Do We Go from Here?}

As this work has demonstrated, many measures have been undertaken to address the harms caused by the IRS policy: criminal trials have convicted abusers and vindicated victims; civil trials have taken school administrators to task for their failures to protect students and have awarded compensation to victims; the ADRP and IAP provided avenues for individual compensation for some types of abuse; the AHF provided survivors and their families with resources to overcome the effects of abuse, including intergenerational effects; the RCAP and TRC published accounts of the IRS system detailing the shortcomings of the care children received in the schools; and two separate apologies acknowledged that the IRS system was founded on a racist policy. Unfortunately, these multiple measures have not addressed the underlying social and political attitudes of successive generations of Canadians who, acting through their government institutions, created the IRS policy that is responsible for so many historical and continuing harms.

I do not know how we, as Canadians, can repair the damage done to IRS survivors, their parents, children, and communities. The reparations we have made to date have not captured the full range of harms stemming from the IRS policy. This is because we have used institutions that only imperfectly recognize the harms caused and largely fail to recognize the broader context of colonialism that led to the IRS policy and through which Canada benefited. I believe that our integrity, and therefore our success, as an intergenerational polity is dependent upon how we engage with our shared history and whether we are willing to take responsibility for both the good and the bad we find within it. 
To do so we must start from the origins of the harms themselves-the racism underlying the IRS policy and our responsibility as members of an intergenerational Canada to recognize the wrongs of our predecessors. Our institutions then become simply tools to be selected and applied as appropriate to recognize the harms experienced and expressed by survivors. We can make this change by looking at the harms caused by the IRS policy through the lens of our responsibility as members of an intergenerational community instead of as the actions of past individuals or governments. We are responsible for the consequences of their actions. We are responsible to each other.

\section{Notes}

1. Truth and Reconciliation Commission of Canada, Canada's Residential Schools: Reconciliation (Montreal \& Kingston: McGill-Queens University Press, 2015) at 3.

2. Maegan Hough, "The Harms Caused: A Narrative of Intergenerational Responsibility"(2019) 56:3 Alberta Law Review 841.

3. Ibid at 848-89.

4. Ibid.

5. Royal Commission on Aboriginal Peoples, Report of the Royal Commission on Aboriginal Peoples: Looking Forward, Looking Back, vol 1 (Ottawa: Supply and Services Canada, 1996) at 378 [RCAP, Report].

6. Marce-Eugène LeBeuf, The Role of the Royal Canadian Mounted Police During the Indian Residential School System (Ottawa: Royal Canadian Mounted Police, 2011) at 412 .

7. Ibid at 415 .

8. Ibid at $428-429$.

9. J.R. Miller, Shingwauk's Vision: A History of Native Residential Schools (Toronto: University of Toronto Press, 1996) at 329.

10. Suzanne Fournier \& Ernie Crey, Stolen From Our Embrace: The Abduction of First Nations Children and the Restoration of Aboriginal Communities (Vancouver: Douglas \& McIntyre, 1998) at 73; $R v$ Plint [1995] BCJ No 3060 (BCSC) (QL); $R v$ Maczynski, 1997 CanLII 2491 (BCCA).

11. Rv Plint, supra note 10 .

12. $R v$ Maczynski, supra note 10.

13. See for example "Former Indian Residential School Employee Charged with Abusing Boys", CBC News Saskatchewan (28 September 2011) online: CBC News<http://www.cbc.ca/news/canada/saskatchewan/ former-indian-residential-school-employee-charged-with-abusing-boys-1.976893>.

14. LeBeuf, supra note 6 at 3. NB: the RCMP was not the police force of jurisdiction in every part of the country at all times in the IRS policy's history.

15. Paulette Regan, Unsettling the Settler Within: Indian Residential Schools, Truth Telling, and Reconciliation in Canada (Vancouver: UBS Press, 2010) at 171. 
16. Jennifer Llewellyn, "Dealing with the Legacy of Native Residential School Abuse in Canada: Litigation, ADR, and Restorative Justice" (2002) 52:3 University of Toronto Law Journal 253 at 266, online: <https://doi.org/10.3138/utlj.52.3.253>; Emily Unrau, "Using Class Actions to Redress Historical Wrongs Committed by the Government" (2013) 8:2 Canadian Class Action Review 339 at 355.

17. Llewellyn, supra note 16 at 266.

18. Fontaine et al $v$ Canada et al, 2006 YKSC 63 at para 47.

19. Ibid at para 5; Northwest v Canada (Attorney General), 2006 ABQB 902; Quatell v Attorney General of Canada, 2006 BCSC 1840; Semple et al $v$ The Attorney General of Canada et al, 2006 MBQB 285; Kuptana v Attorney Gen. of Canada, 2007 NWTSC 01; Ammaq et al v Canada (Attorney General), 2006 NUCJ 24; Baxter v Canada (Attorney General), 83 OR (3d) 481; Bosum v Canada (Attorney General), 2006 QCCS 5794; Sparvier v Canada (Attorney General), 2006 SKQB 533.

20. Jeremy Webber, "Forms of Transitional Justice" in Melissa S Williams, Rosemary Nagy \& Jon Elster, eds, Transitional Justice (New York: New York University Press, 2012) 98 at 111.

21. For a survey of the types of truth commissions, see Priscilla B Hayner, Unspeakable Trutbs: Transitional Justice and the Challenge of Truth Commissions, $2^{\text {nd }}$ ed (New York: Routledge, 2011).

22. Law Commission of Canada, Restoring Dignity: Responding to Child Abuse in Canadian Institutions (Ottawa: Law Commission of Canada, 2000) at 268 [LCC, Report].

23. Schedule 1, Order directing that a Commission under the Great Seal of Canada do issue appointing the following persons to conduct an inquiry and report upon the evolution of the relationship among aboriginal peoples (Indian, Inuit and Métis), the Canadian government and Canadian society, which inquiry shall be known as the ROYAL COMMISSION ON ABORIGINAL PEOPLES, PC 1991-1597 (26 August 1991).

24. Ibid at Schedule I.

25. See for example RCAP, Report, supra note 5 at 333-37, 341, and 375.

26. Ibid at $344 \mathrm{ff}$.

27. Ibid at $353 \mathrm{ff}$.

28. Ibid at 357 .

29. Ibid at 360 .

30. Ibid at $365 \mathrm{ff}$.

31. Ibid at 371-72, 377-78.

32. Kim Stanton, "Canada's Truth and Reconciliation Commission: Settling the Past?" (2011) 2:3 International Indigenous Policy Journal 2 at 2 [Stanton, "Settling the Past?"]. See also RCAP, Report, supra note 5 at 385.

33. RCAP, Report, supra note 5 at 386, recommendation 1.10.3.

34. See for example Janna Thompson, "Apology, Justice, and Respects: A Critical Defense of Political Apology" in Mark Gibney et al, eds, The Age of Apology: Facing Up to the Past (Philadelphia: University of Pennsylvania Press, 2008) 31 at 31. 
35. Matt James, "Wrestling with the Past" in Mark Gibney et al, eds, The Age of Apology, supra note 34 at 140 .

36. Minister of Indian Affairs and Northern Development Canada, "Statement of Reconciliation" in Indian Affairs and Northern Development Canada, Gathering Strength: Canada's Aboriginal Action Plan (Ottawa: Public Works and Government Services Canada, 1997) at 4-5.

37. Jeff Corntassel \& Cindy Holder, "Who's Sorry Now? Government Apologies, Truth Commissions, and Indigenous Self-Determination in Australia, Canada, Guatemala, and Peru" (2008) 9:4 Human Rights Review 465 at 473.

38. Ibid at 473 .

39. James, supra note 35 at 140.

40. Ibid at 141.

41. Regan, supra note 15 at 182-83.

42. Corntassell \& Holder, supra note 37 at 486.

43. Indian Affairs and Northern Development Canada, Gathering Strength, supra note 36 at 25 .

44. Funding Agreement between the Aboriginal Healing Foundation and Her Majesty the Queen of Canada as represented by the Minister of Indian Affairs and Northern Development (31 March 1998), online: <http://www.ahf.ca/downloads/98-fundingagreement.pdf>.

45. Corntassel and Holder, supra note 37 at 473; "FAQs," online: Aboriginal Healing Foundation $<$ http://www.ahf.ca/faqs $>$.

46. "Vision, Mission, Values: The Aboriginal Healing Foundation," online: The Aboriginal Healing Foundation <http://www.ahf.ca/about-us/mission $>$.

47. There are some exceptions like Peter Harrison, "Dispelling Ignorance of Residential Schools" in Gregory Younging et al, eds, Response, Responsibility, and Renewal: Canada's Truth and Reconciliation Journey (Ottawa, The Aboriginal Healing Foundation, 2009) 149.

48. "Funded Projects," online: Aboriginal Healing Foundation < $\underline{\text { http://www.ahf.ca/ }}$ funded-projects>.

49. Aboriginal Healing Foundation, The 2013 Annual Report of the Aboriginal Healing Foundation: Helping Aboriginal People Heal Themselves From the Legacy of Residential Schools (Ottawa, The Aboriginal Healing Foundation, 2013), online: The Aboriginal Healing Foundation <http://www.ahf.ca/downloads/2013-ahf-annual-reportenglish.pdf> at 4.

50. A list can be found at: "Research Series," online: The Aboriginal Healing Foundation $<$ http://www.ahf.ca/publications/research-series $>$.

51. A full list of AHF publications can be found at: "Publications," online: The Aboriginal Healing Foundation $\langle$ http://www.ahf.ca/publications $>$.

52. See for example Bryn Weese \& Christina Spencer, "Native Leaders Slam Closing of Healing Foundation", Winnipeg Sun (29 March 2009), online: Winnipeg Sun <http://www.winnipegsun.com/news/canada/2010/03/29/13402886.html>. 
53. Truth and Reconciliation Commission of Canada, Truth and Reconciliation Commission of Canada Interim Report (Winnipeg: Truth and Reconciliation Commission of Canada, 2012), Recommendation 16 at $10 \& 29$.

54. Regan, supra note 15 at 121.

55. Glenn Sigurdson, Reconciliation and Healing: Alternative Resolution Strategies for Dealing with Residential Schools Claims (Ottawa: Minister of Indian Affairs and Northern Development, 2000), online: Glenn Sigurdson <http://www. glennsigurdson.com/wp-content/uploads/2010/09/Reconciliation healing.pdf $>$ at $106 \mathrm{ff}$.

56. Kaufman, Thomas \& Associates, Review of Indian Residential Schools Dispute Resolution Projects: Executive Summary (Toronto: Indian Residential Schools Resolution Canada, 11 October 2002) at (ii) [Kaufman, "Executive Summary"].

57. Regan, supra note 15 at 122.

58. Kaufman, "Executive Summary," supra note 56 at (ii).

59. Kaufman, Thomas \& Associates, Review of Indian Residential Schools Dispute Resolution Projects: Final Report (Toronto: Indian Residential Schools Resolution Canada, 11 October 2002) at 39 [Kaufman, "Final Report"].

60. Regan, supra note 15 at 202.

61. Ibid at 198.

62. Ibid at 199.

63. Ibid at 200 .

64. Ibid at 200.

65. Ibid at 203-04.

66. Ibid at 206.

67. Ibid at 208 .

68. Ibid at 121.

69. Ibid at 122 .

70. Kaufman, "Executive Summary," supra note 56 at (xx).

71. Standing Committee on Aboriginal Affairs and Northern Development, "Study on the Effectiveness of the Government Alternative Dispute Resolution Process for the Resolution of Indian Residential School Claims" (Ottawa, March 2005), online: Parliament of Canada <https://www.ourcommons.ca/DocumentViewer/en/38-1/ $\underline{\text { AANO/report-4>. }}$

72. Regan, supra note 15 at 123.

73. Ken Halvorson, Indian Residential Schools Abuse Claims: A Lawyer's Guide to the Adjudicative Process (Toronto: Thomson Canada, 2005) at 2.

74. Regan, supra note 15 at 123.

75. Ibid.

76. Halvorson, supra note 73 at 9 .

77. Ibid at 8 .

78. Ibid at 41 .

79. Ibid at 17-18. 
80. Ibid at 61 .

81. Ibid at 69-73, 104.

82. Quoted in Regan, supra note 15 at 131.

83. Regan, supra note 15 at 124.

84. Regan, supra note 15 at 124 quoting from Assembly of First Nations, "Report on Canada's Dispute Resolution Plan to Compensate for Abuses in Indian Residential Schools" (2004) [AFN, Report].

85. AFN, Report, supra note 84 at 13.

86. Ibid, Recommendations 12 and 13 at 26-27.

87. Regan, supra note 15 at 134 .

88. Ibid at 125 .

89. Standing Committee on Aboriginal Affairs and Northern Development, supra note 71.

90. Halvorson, supra note 73 at 6 .

91. Indian Residential Schools Settlement Agreement (8 May 2006) online: <www. residentialschoolsettlement.ca> [IRSSA], Article 3.02.

92. Ibid at Article 8.01 (1).

93. Ibid at Schedule M, Preamble.

94. Jenny Edkins, Trauma and the Memory of Politics (Cambridge: Cambridge University Press, 2003) at 94.

95. IRSAA, supra note 91 at Article 3.04, Schedule "J."

96. Ibid at Commemoration Policy Directive, Schedule "J."

97. Ibid.

98. Crown-Indigenous Relations and Northern Affairs Canada, "Commemoration 2011-2012 - Project Descriptions," online: <https://www.rcaanc-cirnac.gc.ca/eng 11370974213551/1370974338097>; Crown-Indigenous Relations and Northern Affairs Canada, "Commemoration 2012-2013-Project Descriptions," online: <https://www.rcaanc-cirnac.gc.ca/eng/1370974253896/1370974471675>.

99. Crown-Indigenous Relations and Northern Affairs Canada, "Stained Glass Window in Parliament Commemorating the Legacy of Indian Residential Schools," online: $\langle$ https://www.rcaanc-cirnac.gc.ca/eng/1354805080035/1571583169450>.

100. LCC, Report, supra note 22 at 207.

101. IRSSA, supra note 91 at Article 5.02.

102. Ibid at 12 .

103. Residential Schools Official Court Notice, "Personal Credits," online: Indian Residential Schools Settlement - Official Court Website <www.classactionservices.cal irs/Personal Credits/PCA-Home.htm >.

104. IRSSA, supra note 91 at Article 5.07 (1) and (2).

105. Crown-Indigenous Relations and Northern Affairs Canada, "Statistics on the Implementation of the Indian Residential Schools Settlement Agreement" (19 February 2018), online: <https://www.rcaanc-cirnac.gc.ca/eng/1315320539682/13 $15320692192>$.

106. AFN, Report, supra note 89 at 3,18-19. 
107. Gwen Reimer (Praxis Research Associates), The Indian Residential Schools Settlement Agreement's Common Experience Payment and Healing: A Qualitative Study Exploring Impacts on Recipients (Ottawa: The Aboriginal Healing Foundation, 2010) at 5.

108. Fontaine, supra note 18 at para 48.

109. Reimer, supra note 107 at 44.

110. Ibid at xiii.

111. Ibid at $44 \mathrm{ff}$.

112. Ibid at xiii (NB: this was only $10 \%$ of recipients in the study).

113. For a detailed account of the recommendations of the AFN see AFN, Report, supra note 84.

114. IRSSA, supra note 91, Schedule D at 3-6.

115. Ibid, Schedule D at 2.

116. Ibid, Schedule D at 12 .

117. Ibid, Schedule D at 34 and 35 .

118. Ibid, Schedule D at 34 .

119. Ibid, Schedule $\mathrm{D}$ at 35 .

120. Crown-Indigenous Relations and Northern Affairs Canada, "Statistics on the Implementation of the Indian Residential Schools Settlement Agreement" (24 August 2019), online: <https://www.rcaanc-cirnac.gc.ca/eng/1315320539682/131 5320692192>.

121. Ibid.

122. Stanton, "Settling the Past?" supra note 32 at 4.

123. IRSSA, supra note 91 at Article 3.03 (1).

124. Ibid, Schedule "N": Mandate for the Truth and Reconciliation Commission.

125. Ibid, Schedule N 1. (a) at 1.

126. Ibid, Schedule N 1. (d) at 2.

127. Ibid, Schedule N 1. (f) at 2.

128. Kim Stanton, "Looking Forward, Looking Back: The Canadian Truth and Reconciliation Commission and the Mackenzie Valley Pipeline Inquiry" (2012) 27:1 Canadian Journal of Law and Society 81 at 95, 97 [Stanton, "Pipeline"].

129. Rosemary Nagy, "The Scope and Bounds of Transitional Justice and the Canadian Truth and Reconciliation Commission” (2012) International Journal of Transitional Justice 1 at 13 .

130. Fontaine v (Canada) Attorney General, 2013 ONSC 684 at paras 97-99.

131. TRC, Interim Report, supra note 53.

132. Truth and Reconciliation Commission of Canada, They Came for the Children: Canada, Aboriginal Peoples, and Residential Schools (Winnipeg: Truth and Reconciliation Commission of Canada, 2012).

133. TRC, Final Report, vol 6, supra note 1 at $223 \mathrm{ff}$.

134. IRSSA, supra note 91, Schedule N 2. (b), (d) at 3.

135. Ibid, Schedule N 2. (f) at 3.

136. Ibid, Schedule N 4. at 5 .

137. Stanton, "Settling the Past?" supra note 32 at 6. 
138. "Remaining 2 Members Resign from Residential Schools Commission", $C B C$ News (30 January 2009), online: CBC News <http://www.cbc.ca/news/canada/ remaining-2-members-resign-from-residential-schools-commission-1.781852 >.

139. "TRC Ready to again Take Residential School Document Fight with Ottawa to Court", APTN (30 April 2013), online: APTN <http://aptn.ca/pages/ news/2013/04/30/trc-ready-to-again-take-residential-school-document-fightwith-ottawa-to-court/>; Canada (Attorney General) v Fontaine, 2017 SCC 47.

140. Letter from Justice Harry Laforme to the Honourable Chuck Strahl, Minister of Indian Affairs and Northern Development (20 October 2008), online: <https://www.theglobeandmail.com/news/national/ resignation-paralyzes-residential-schools-commission/article20388682/>.

141. Stanton, "Settling the Past?" supra note 32 at 8.

142. Kim Stanton, "Reconciling Reconciliation: Differing Conceptions of the Supreme Court of Canada and the Canadian Truth and Reconciliation Commission," (2017) 26:1 Journal of Law and Social Policy, online: <https://digitalcommons.osgoode. yorku.ca/j1sp/vol26/iss1/2> at 34 [Stanton, "Reconciling"].

143. Stanton, "Pipeline," supra note 128 at $95,97$.

144. Marc A. Flisfeder, "A Bridge to Reconciliation: A Critique of the Indian Residential School Truth Commission" (2010) 1:1 The International Indigenous Policy Journal 3, online: <https://doi.org/10.18584/iipj.2010.1.1.3 > at 1.

145. TRC, Final Report, Vol 2, supra note 1 at 74.

146. TRC, Final Report Vol 6, supra note 1 at 223.

147. Ibid at 11.

148. Ibid at 46.

149. Stanton, "Reconciling," supra note 142 at 36; Justin Trudeau "Statement by Prime Minister of Canada on Release of the Final Report of the Truth and Reconciliation Commission" (15 December 2015), online: <https://pm.gc.ca/ eng/news/2015/12/15/statement-prime-minister-release-final-report-truth-andreconciliation-commission>.

150. Crown-Indigenous Relations and Northern Affairs Canada, "Delivering on Truth and Reconciliation Commission Calls to Action,” online: <https://www.rcaanccirnac.gc.ca/eng/1524494530110/1557511412801>

151. CBC News Interactive, "Beyond the 94: Truth and Reconciliation in Canada," online: <https://newsinteractives.cbc.ca/longform-single/beyond-94? \&cta=1> (updated January 2020). As of January 2020 the CBC reports that 10 CTAs are complete, 60 are in progress with projects proposed or underway, and 24 "not started."

152. Paulette Regan, "Reconciliation and Resurgence: Reflections on the TRC Report" in Michael Asch, John Borrows \& James Tully, eds, Resurgence and Reconciliation Indigenous-Settler Relations and Earth Teachings (Toronto: University of Toronto Press, 2018) at 213. 
153. Eva Mackey, “The Apologizers' Apology” in Jennifer Henderson \& Pauline Wakeham, eds, Reconciling Canada: Critical Perspectives on the Culture of Redress (Toronto: University of Toronto Press, 2013) 47 at 47.

154. House of Commons Debates, 39 $9^{\text {th }}$ Parl $2^{\text {nd }}$ Sess, No 110 (11 June 2008) at 1515 ff (Right Hon. Stephen Harper (Prime Minister)), online: Parliament of Canada <http:www.parl.gc.ca/HousePublications/aspx? Language=1\&Parl=39\&Ses+2\&Do

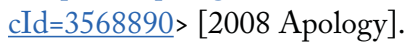

155. Mackey, supra note 153 at 47.

156. Douglas Sanderson "Redressing the Rights Wrong: the Argument from Corrective Justice" (2012) 62:1 University of Toronto Law Journal 93 at 101, online: <https://doi.org/10.3138/utlj.62.1.93>.

157. Mackey, supra note 153 at 53.

158. Ibid at 54 .

159. Ibid at 55-56.

160. Ibid at $57-58$.

161. "Aboriginal Children Used in Medical Tests, Commissioner Says", $C B C$ News (31 July 2013) online: CBC News <http://www.cbc.ca/news/politics/ aboriginal-children-used-in-medical-tests-commissioner-says-1.1318150>.

162. “Hungry Aboriginal People Used in Bureaucrats' Experiments", The Canadian Press (16 July 2013) online: CBC News <http://www.cbc.ca/news/canada/manitoba/ hungry-aboriginal-people-used-in-bureaucrats-experiments-1.1317051>.

163. Michael Woods, "Tories Called to Honour Indian Residential Schools Apology", Postmedia Nerws (23 July 2013), online: Canada.com < http://o.canada.com/news/ tories-called-to-honour-indian-residential-schools-apology-amid-aboriginalnutritional-experiments-controversy/>.

164. Jody Porter, "No New Apology for Residential School Experiments", CBC Nerws (9 August 2013), CBC News Thunder Bay,online:<http://www.cbc.ca/news/canada/ thunder-bay/no-new-apology-for-residential-school-experiments-1.1343989>.

165. See for example: Shawn A-in-chut Atleo, National Chief, Assembly of First Nations, "Honour the Apology to Residential School Survivors" (25 July 2013), online: The Assembly of First Nations <http:/www.afn.ca/index.php/en/news-media/latestnews/honour-the-apology-to-residential-school-survivors-july-25-2013>; “150 Attend Interfaith Honour the Apology Rally", CBC News (25 July 2013), online: CBC News <http://www.cbc.ca/news/canada/manitoba/150-attend-interfaithhonour-the-apology-rally-1.1313302 >; Wab Kinew, "Honour the Apology: Fasting for My Father, a Residential School Survivor", The Huffington Post (25 July 2013) online: HuffPost Politics Canada <http://www.huffingtonpost.ca/wab-kinew/ honour-the-apology-rally b 3651506.html $>$.

166. Sanderson, supra note 156 at $118 \mathrm{ff}$. 
167. Bill C-91, An Act respecting Indigenous languages, $1^{\text {st }}$ sess, $42^{\text {nd }}$ Parl, 2019 (first reading 5 February 2019).

168. Bill C-92, An Act respecting First Nations, Inuit and Métis children, youth and families, $1^{\text {st }}$ sess. $42^{\text {nd }}$ Parl, 2019 (first reading 28 February 2019).

169. Department of Justice Canada, news release "Government of Canada Supports the Wahkohtowin Law and Governance Lodge and Launches a Call for Proposals for the Revitalization of Indigenous Laws" (14 August 2019), online: <https://www. canada.ca/en/department-justice/news/2019/08/government-of-canada-supportsthe-wahkohtowin-law-and-governance-lodge-and-launches-a-call-for-proposalsfor-the-revitalization-of-indigenous-laws.html>.

170. Hough, supra note 2.

171. Ibid.

172. Ibid. See also Iris Marion Young, Responsibility for Justice (Oxford: Oxford University Press, 2011) at 80.

173. Regan, supra note 15 at 34-36; John Torpey, "Introduction" in John Torpey, ed, Politics and the Past: On Repairing Historical Injustices (Lanham, MD: Rowman and Littlefield, 2003) at 18.

174. Janna Thompson, Intergenerational Justice: Rights and Responsibilities in an Intergenerational Polity (New York: Routledge, 2009) at 77-78.

175. Iris Marion Young, Responsibility for Justice, supra note 172 at 98.

176. “AFN/AHF Commemoration Proposal" (Assembly of First Nations and Aboriginal Healing Foundation) in Crown-Indigenous Relations and Northern Affairs Canada, “Commemoration 2012-2013 - Project Descriptions," supra note 98.

177. "Restoring Reconciliation" (National Capital Radio Association), ibid.

178. Canada (Attorney General) v Fontaine, supra note 139 at para 60.

179. Roger I Simon, “Towards a Hopeful Practice of Worrying: The Problematics of Listening and the Educative Responsibilities of Canada's Truth and Reconciliation Commission" in Jennifer Henderson \& Pauline Wakeham, eds, Reconciling Canada: Critical Perspectives on the Culture of Redress (Toronto: University of Toronto Press, 2013) 129 at 136.

180. TRC, "Interim Report," supra note 53 at 33.

181. "National Research Centre on Indian Residential Schools", online: The Truth and Reconciliation Commission of Canada <http://www.trc.ca/websites/trcinstitution/ index.php? $\mathrm{p}=815>$.

182. “N.W.T., Nunavut Launch Residential School Curriculum”, CBC Nerws (2 October 2012), online: CBC News <http://www.cbc.ca/news/canada/ north/n-w-t-nunavut-launch-residential-school-curriculum-1.1183964>.

183. John Cotter, "Alberta Students to be Taught LegacyofIndian Residential Schools", The CanadianPress(28March2014), online:CTVNews < http://www.ctvnews.ca/canada/ alberta-students-to-be-taught-legacy-of-indian-residential-schools-1.1750176>. 
184. "World's First Indigenous Law Program Launches with Historic and Emotional Ceremony"(22 October 2018), online: <https://www.uvic.ca/news/topics/2018+jidprogram-launch+news >; "New Initiative Promises Community-Led Research on Indigenous Law and Governance”(6 February 2019), online: <https:/www.ualberta. ca/law/about/news/main-news/2019/february/new-initiative?fbclid=IwAR3eHxh ob110hVYYimhvua fdporqwoqw6Ok5Dp9T32WKWiKX nBQ0jYw4g>.

185. Teresa Godwin Phelps, Shattered Voices: Language, Violence, and the Work of Truth Commissions (Philadelphia: University of Philadelphia Press, 2004) at 55.

186. Ibid.

187. Ibid.

188. Ibid at 59 .

189. Ibid at 69-70.

190. See for example Sanderson, supra note 156; Kirsten Anker, "Reconciliation in Translation: Indigenous Legal Traditions and Canada's Truth and Reconciliation Commission" (2016) 33:2 Windsor Yearbook of Access to Justice 15, online: < doi. org/10.22329/wyaj.v33i2.4842>.

191. TRC Report Vol 6, supra note 1 at 46.

\section{Acknowledgements}

This article is adapted from my LLM thesis completed under the thoughtful guidance of Professors Jeremy Webber and Matt James at the University of Victoria, and with financial support from the Social Sciences and Humanities Research Council of Canada. Additional thanks are due to Professor Hadley Friedland, Dr Ron Stevenson, and Hannah Wyile for their constant encouragement, and to the editors and anonymous peer reviewers for their insightful suggestions. All errors or omissions are my own.

\section{Author}

Maegan Hough, BA (Hons.), LLB/BCL, LLM, is legal counsel with the Department of Justice Canada. The views and opinions expressed in this article are entirely those of the author and do not reflect those of the Department of Justice or the Government of Canada. 